\title{
Wu Mi as a New Humanistic Translator
}

\author{
Gang Wang \\ School of Foreign Languages, Sun Yat-sen University, Guangzhou 510275, China. \\ wgjack912@126.com
}

Keywords: Wu Mi, translation, New Humanism.

\begin{abstract}
Wu Mi, one of the chief cultural celebrities during the Republic Period, has been crowned with many titles, such as a poet, a master in Chinese classics, an expert in western literature, the forefather of China's comparative literature and leader of the Critical Review School. However, his identity as a great translator has not been fully recognized in spite of the fact that he had been giving lectures on The Art of Translation for many years and had produced many translations that were not less significant than his academic writings. The crucial role of translation in Wu Mi's academic life, together with the bearings of his unswerving belief in New Humanism upon his translations, has not been sufficiently dealt with among the limited researches that the past two decades have seen. In this paper, a short survey of what he had translated will be offered, and an analysis into why he chose to translate those specific texts will be made. The purpose is not only to demonstrate Wu Mi's greatness as a translator, but more importantly, to show the close link between his translations and the New Humanistic ideal he embraced.
\end{abstract}

\section{Introduction}

Wu Mi, widely known during the Republican Period not only as a poet but also as the leader of the Critical Review School that stood in direct opposition to the radical Neo-Cultural School, is also famous for his erudition in Chinese classics and expertise in western literature. His cultural ideal had not been widely accepted, compared with those upheld by people from the New Culture camp. The criticisms he and his colleges waged towards the New Culture Movement was often responded with even sharper returns. And he remained nearly obscure during the last 28years of his life and the decade after his death in 1978. However, since the ends of 1980s and the beginning of 1990s, research interest in Wu Mi began to accumulate. His theory of literary criticism, his thoughts on education, his contribution to China's comparative literature and Studies on A Dream of Red Mansion (Hongxue), his view on cultural reconstruction, and even his personal character, have attracted wide attention. The same period has also witnessed a dramatic change in the discipline of Translation Studies both home and abroad. Internationally, the "cultural turn" [1] ushered in a golden stage for the fledging discipline, while in mainland China the discipline was gradually established and has been burgeoning ever since. But it should be noted that growing in academic interest in Wu Mi and the burgeoning of Translation Studies over the past two decades have not brought with them a corresponding increase in the study of his translation. Wu Mi is remembered for many different titles except a great translator. His translations have not been systematically surveyed or fairly examined. Neither have his thoughts on translation been wholly summarized or properly interpreted.

New Humanism was claimed by Wu Mi himself to be the central principle upon which his academic thoughts were based [2, 3]. It was not only confirmed by Miu Yue, one of his close friends 
and former colleagues [4], but can also be testified by the traces of New Humanism easily found in the whole array of his academic thoughts. It can be inferred, therefore, that his thoughts on and practice of translation, with which his cultural ideas, literary criticisms and views of comparative literature are closely connected, could not be soundly interpreted if not from the perspective of New Humanism. however, the larger project of demonstrating that Wu Mi is a New Humanistic translator cannot be finished in just one go. In this paper, what $\mathrm{Wu}$ Mi has translated will be delineated, and more importantly, how his New Humanistic ideal influenced his choice of original texts will be explored, serving as part of the above-mentioned project.

\section{Wu Mi’s Achievement as A Translator}

Wu Mi's reputation as a great translator could not be established without a complete survey of what he has actually translated. For a long time, the importance of translation in Wu Mi's career either as a renowned scholar, a great poet, or a far-sighted educator has not been fully realized. For him, translation is a good starting point for literary creation because it is the best means of imitation which constitutes one of the three stages for creation [5]. Moreover, "a good translation in which the spirit of the original is fully transplanted has almost reached the level of literary creation" [5]. For him, Translation is also the key means by which classics of western literature and ideas of New Humanism were introduced to the Chinese audience and by which his New Humanistic ideal was put into practice. And it should be remembered that he has left to us rich legacies concerning ideas of translation shown through his discourse on translation.

Chronologically Wu Mi's career of translation can be roughly divided into two periods: the earlier period when he was attending preparatory courses in Tsinghua School (from 1911 to 1917) and when he pursued his study in the U.S. after that (from 1917 to 1921), and the later period since he returned back to China and took up the post of editor in chief for the newly founded journal The Critical Review in 1922. The major works during the earlier period were his translation of Henry Longfellow's epic poem Evangeline in the form of traditional Chinese opera and his translation of Orison Swett Marden's Pushing to the Front. However, it is during the later period that translation was given full play, in so far as both its quantify and quality are concerned. Therefore, in this study, only those translations finished during the later period will be examined.

Wu Mi's translations consist of two broad categories: (1) academic and (2) literary, each of which consists of two more subcategories. While the former contains (1.1) the translation of general surveys of western literature or world literature and (1.2) the introduction of New Humanism and academic thoughts closely related to it, the latter contains (2.1) novel translation and (2.2) poetry translation. Among his academic translations, (1.1) is made up of 8 works embodied by his partial translation of The Legacy of Greece [6], The Legacy of Rome [7], and Literature of the World: An Introductory Study [8], while the number of those under the subcategory (1.2) is 17 with the translations of Irving Babbitt's writings and academic thoughts as representatives. His novel translation (2.1) consists of the rendering of the first six chapters of The Newcomes and the first chapter of Vanity Fair, both of which were written by the Victorian novelist William Thackeray. And according to Collected Poems of Wu Mi [9], in which most of his poetry translations are collected, he has translated 44 poems, in addition to a few others not collected in the book.

Nearly all his academic translations were published in The Critical Review. So were the majority of his translated poems. As to the source of those texts, most of them were from English. A few of them were from French. In addition to that, he also translated two poems from Latin.

This is a short survey of Wu Mi's translations. Compared with some of his contemporaries, he was not so productive as a translator. Still, the rich varieties that his translations covered, together 
with the fact that he had been giving lectures on The Art of Translation for many years and had produced a number of insightful discourses on translation, would suffice to justify his status as one of the great translators during the Republic period. However, a clearer view of the importance of translation in his academic life and a fuller justification of his role as a humanistic translator can be presented when an in-depth analysis of his practice of as well as thoughts on translation is made. But before that a brief account of New Humanism must be given.

\section{New Humanism and the Task of a Humanistic Translator}

The summer of 1918 is marked as the beginning of Wu Mi's life-long pilgrimage as a staunch follower of New Humanism when he was introduce by Mei Guangdi to Irving Babbitt and Paul Elmer More, the former being the leader of that movement and his adviser during his study in Harvard, while the latter being its chief practioner. As New Humanism was acknowledged to be the cornerstone of his academic thoughts, a brief introduction of it must be made so that its possible projections upon translation can be seen.

New Humanism, or American humanism as was termed by Mercier, refers to "the efforts made in the United States to restore the conception that man is unique in nature, that he is both spirit and matter, so that he cannot be the product of a purely material evolution” [10]. Simply put, it refers to the critical movement that happened during the first several decades of the $20^{\text {th }}$ century, with Irving Babbitt and Paul Elmer More as its leaders and chief critical thinkers. It calls for a "rebirth" or "renaissance" of humanism, that is, to restore "the something in his nature that sets him apart from simply as man from other animals" [11]. By insisting the dualistic view of human nature and stressing the importance of balance, harmony or mediation between the two parts of man, i.e. the higher part and lower part characterized by “One” and "Many” respectively, New Humanism poised as a direct challenge to monistic naturalism according to which the lower part of man is overstated. The modern era was marked with monistic naturalism of various sorts. "The law for things" was taking the upper hand while "the law for man" was thrown aside and neglected. Man was either reduced to things or ranked along the lower beings. The sense of measure and constraint implied in the word "humanism" was gradually lost, leading to its appropriation by "humanitarianism" [12]. And the encroachment of monistic naturalism in modern society could be found in many different fields, such as college education, literary creation and criticism, philosophy, and politics, causing the debauchment of man and the decadence of civilization. Therefore, by reaffirming "the something in himself that is set above flux and that he possesses in common with other men" [11] and referring constantly to the classics of the world, humanistic scholars hoped to save western civilization from falling further into the state of barbarism.

The task of a true humanist is to form the complete man or to forge the rounded development of the individual by stressing "the law of measure" or by harmonizing "the One” with "the Many" [12]. To put it in a larger sense, it is to "organize our huge inheritance of culture, to make the past available to the present, to make the whole of civilization available to men who necessarily live in one small corner for one little stretch of time, and finally to judge, as a critic, the actions of the present by the experience of the past" [13]. Or to be more precise, it is to "add to the limited experimentation possible to one age the wisdom of the ages, a wisdom that one may achieve by an imaginative concentration not only on our own experience and that of our time but on the experience of the race, to be found in history and especially in the records of the thoughts of its greater witnesses" [14]. It means that in order to reconstruct a culture which is aimed at sound and complete development of the individual, a truly humanistic scholar would not be led astray by what lies before his eyes that are relative and adrift in nature. Nor would he be indulged in the 
gratification of his lower impulses or expansive desires. Rather, he would constantly resort to the glorious traditions or classics in which "the law for man" or true human nature has been fully embodied. While making the huge cultural heritage accessible to the modern age, he would also go through a constant process of hard and clear thinking. He would embrace the past in a positive and critical manner rather than being a traditionalist, so that the experience of the past can be adjusted to the changing needs of the present [15].

It can be seen, therefore, that the humanistic insistence upon balancing the two parts of man is reflected in the idea of bringing the past into the present. And the task of a truly humanistic translator is not incongruent with that of a humanist. His job is to introduce through his translations the cultural heritages and classics from other nations, so that the whole of civilization can be used to the greatest extent, so that a genuinely new culture that draws on deeper understanding of man, wider range of human wisdom, and larger scales of fusion between the tradition and the modern, would be constructed.

\section{New Humanistic Ideal and the Choice of Original Texts}

A translator is "humanistic" not only in the sense of how he actually translates, but first of all in the sense of what he chooses to translate. And after a short survey of what Wu Mi has translated and a quick inquiry into the main ideas of New Humanism, this part will be dedicated to exploring the inter-relations between his New Humanistic ideal and his choice of original texts, so that his status as a great humanistic translator can be partially justified.

In order to bring the past into the present for the reconstruction of new culture and for humanistic edification of the individual, the humanist scholar has to go through the process of value judgement and humanistic criticism. That is, different traditions and cultural heritages must be scrupulously weighed, carefully assessed and reinterpreted according to the standard of human nature before they are brought to bear on the present and fuse with the modern. The same is true for the truly humanistic translator. He needs to choose "the best that has ever been thought and said" [16]. While the loss of standard has caused both anarchy in literary creation and chaos in literary criticism, as was extensively argued by Irving Babbitt [15], the humanistic idea of measure together with representativeness and universality rather than flux or relativity enables the translator to sift through the large matrix of original texts, so that those that are in line with the humanistic ideal or could reveal "the law for man" to the fullest extent will be selected.

Translation for Wu Mi is the key means by which "a genuine new culture” instead of the kind advocated by those from the New Culture camp such as Chen Duxiu and $\mathrm{Hu}$ Shi could be constructed. New culture, according to $\mathrm{Wu} \mathrm{Mi}$, does not necessarily mean the repudiation of our own tradition and the Europeanizing of China. Rather, it should be the result of integrating glorious heritages of both east and west, and it could not be effectively constructed without fusing the past with the present. Therefore, he suggested that Chinese cultural traditions should be scrupulously reserved, re-interpreted and carried forward into the new era. Western cultural traditions and classics should also be massively translated in order of their importance or essential values. And he went on to say that "cultural legacies of the west are shining like diamonds in front of us. Although we are free to choose whatever we want, still we need to assess prudently and choose wisely” [17]. In the editor's note prefixed to a translation published in the Critical Review, he even stated clearly the principle of selecting the original text: "The original texts are often strictly selected. They must be classics and have been tested by time, be it proses, poems, novels, or philosophical writings.”[18] And it is not difficult to figure out the conformity of this statement with his New Humanistic ideal.

Now let's turn to Wu Mi's translations and try to figure out how much the New Humanistic 
ideal he had been upholding and practicing bears on his choice of original texts. To be more precise, we will investigate the humanistic motivations that underlie Wu Mi's selection of original texts.

Academic Translation. The humanistic nature of $\mathrm{Wu}$ Mi's translation can be illustrated first of all by his academic translations. The two categories have already been delineated: western classics and New Humanism. That Wu Mi had translated some of the ancient Greek and Roman classics has been pointed out. And it should be noted that the Critical Review, under his leadership, was the first front during that time for the introduction of Greek classics, such as the translation of Plato's dialogues and Aristotle's Ethics. What's more, the writings of New Humanistic writers, and academic writings that echoing or supporting New Humanistic ideal were also preferred. If not for his belief in New Humanism, those classics and humanistic writings would not have been selected.

Poetry Translation. Among Wu Mi's translated poems, a great many appeared in his academic translations, which means that those poems were "thrust" upon him and were not purposefully chosen. However, due to the texts in which they occurred, those poems are also tinged with the bright color of New Humanism. Roughly speaking, the poems Wu Mi translated can be divided into two categories according to thematic matters. One the one hand, we have poems that are concerned with human nature and the general Law. This category is represented by his selected translation of Bhagavada Gita, a text which his adviser Irving Babbitt drew heavily on for the establishment of his humanism. On the other hand, we have seen poems that deal with genuine but heightened and disciplined emotions. According to the classical understanding of literature, it is due to such emotions that poems are endowed with high seriousness. And this category is represented by poems by Matthew Arnold and Christina Rossetti, both of whom were claimed to his favorite. Judging from the thematic matters of his translated poems, we can easily figure out the direct influence of his humanistic ideal upon the kind of poems he chose to translate.

Novel Translation. Although Wu Mi had translated two novels, he left both of them unfinished. However, this will not prevent us to reach the conclusion that New Humanism plays a central role in motivating $\mathrm{Wu} \mathrm{Mi}$ to undertake those translations. Thackeray was deemed by $\mathrm{Wu} \mathrm{Mi}$ as equally great with another Victorian novelist Charles Dickens, but he was rarely known in China, compared with the high reputation the latter enjoyed due to Lin Shu's translation. However, that is just one reason why he chose to translate the former. The more basic reason is his appreciation of the novel, his contrast of the Thackeray with Dickens, and his comparison of Thackeray with the Chinese classical novelist Cao Xunqin. Under close scrutiny and in-depth analysis, Wu Mi concluded that Thackeray was a far greater novelist than Dickens and that The Newcomes instead of Vanity Fair was the greatest of all Thackeray's novels when measured with the six requirements of a good novel proposed by his teacher Dr. Maynadier in Harvard. And that system of novel criticism can be found to be in full compliance with the classical spirit. Wu Mi would like to introduce to the Chinese audience a classical novel that could almost rival with the Chinese classics A Dream of Red Mansion in artistic achievements. Although Thackeray's two novels has been translated by a few others later on, none of those translators managed to reach such a deep understanding evidenced in his in-text notes, the translator's foreword and afterword. Therefore, it can be said that it is largely his humanistic pursuit that draws Wu Mi to undertake the task of translating Thackeray.

\section{Summary}

When the activists from the New Culture School were brandishing the banner of science and democracy, and were advocating a kind of translation that best suited their revolutionary appeal, $\mathrm{Wu}$ Mi was endeavoring to introduce New Humanism. And translation plays a crucial role in his attempt to introduce as well as to practice that ideal. That's why the position of translation in his academic 
life should be acknowledged. And the two-way relations between his new humanistic ideal and his translations must be investigated, so that his role as a great humanistic translator could be firmly established. That goal is partially fulfilled in this paper by examining the bearing of his humanistic ideal upon his choice of original texts. The influence of his New Humanistic ideal upon his methods of translation will examined later.

\section{References}

[1] S. Bassnett, A. Lefevere (Eds.), Translation, History and Culture, London and New York: Routledge

[2] F. Rui, Professor Wu Mi on literature and life, in: S. Huang (ed.), In Memory of Mr. Wu Mi, Shaanxi People’s Publishing House, Xi’an, 1990, pp. 173-175.

[3] M. WU, Literature and Life, Tsinghua University Press, Beijing, 1996.

[4] Y. Miu, In memory of Mr. Wu Mi, in: S. Huang (ed.), In Memory of Mr. Wu Mi, Shaanxi People's Publishing House, Xi'an, 1990, pp. 1-9.

[5] M. Wu, On the right way of literary creation in current China, Critical Review 15 (1923) 7-33.

[6] G. Murray, The value of Greece to the future of the world, in: R.W. Livingston (ed.), The Legacy of Greece, The Clarendon press, Oxford, 1921, pp.1-23.

[7] H. Last, Family and social life, in: C. Bailey (ed.), The Legacy of Rome, The Clarendon Press, Oxford, 1923, pp. 209-236.

[8] W. L. Richardson, J. M. Owen, Literature of the World: An Introductory Study, Ginn and Company, Boston, 1922.

[9] M. Wu, Collected Poems of Wu Mi, The Commercial Press, Beijing, 2004.

[10] L. J. Mercier, American Humanism and the New Age, The Bruce Publishing Company, Milwaukee, 1948.

[11] I. Babbitt, Humanism: an essay at definition, in: N. Forester (ed.), Humanism and America: Essays on the Outlook of Modern Civilization, Farrar and Rinehart, 1930, pp. 25-51.

[12] I. Babbitt, Literature and the American College: Essays in Defense of the Humanities, Houghton Mifflin Company, Boston \& New York, 1908.

[13] R. Schlatter, Foreword, in: W. Sutton, Modern American Criticism, Prentice-Hall Inc., New Jersey, 1963, pp. vii-x.

[14] L. J. Mercier, The Challenge of Humanism: An Essay in Comparative Criticism, Oxford University Press, New York, 1933.

[15] I. Babbitt, The Masters of Modern French Criticism, Houghton Mifflin Company, Boston and New York, 1912.

[16] M. Arnold, Culture and Anarchy, Macmillan, New York, 1925.

[17] M. Wu, On new culture movement, Critical Review 4 (1922) 31-53.

[18] M. Wu, The editor's preface to the translation of Dream-Children: A Reverie, Critical Review 9 (1922) 101. 